\title{
Anatomical Characteristics of African Cherry (Prunus Africana) Medicinal Plant for its Accurate Taxonomic Identification
}

\section{Richard Komakech}

Natural Chemotherapeutics Research Laboratory

\section{Sungyu Yang}

Korea Institute of Oriental Medicine

Jun Ho Song

Korea Institute of Oriental Medicine

Choi Goya

Korea Institute of Oriental Medicine

\section{Kim Yong-Goo}

Korea Institute of Oriental Medicine

\section{Francis Omujal}

Natural Chemotherapeutics Research Laboratory

Grace Nambatya Kyeyune

Natural Chemotherapeutics Research Laboratory

Gilbert Motlalepula Matsabisa4

University of the Free State

Youngmin Kang ( $\nabla$ ymkang@kiom.re.kr)

KIOM: Korea Institute of Oriental Medicine https://orcid.org/0000-0003-0184-6115

\section{Original Article}

Keywords: Botany, Anatomy, Prunus africana, Species, Taxonomy.

Posted Date: August 24th, 2021

DOI: https://doi.org/10.21203/rs.3.rs-823299/v1

License: (c) (i) This work is licensed under a Creative Commons Attribution 4.0 International License.

Read Full License 


\section{Abstract}

Background: The genus Prunus (Family Rosaceae) comprises over 400 plant species and exhibits vast biodiversity worldwide. Due to its wide distribution, its taxonomic classification is important. Anatomical characters are conserved and stable and thus can be used as an important tool in plant taxonomic characterization. Thus, this study aimed at examining and documenting $P$. africana leaf, stem, and seed anatomy using micrographs and photographs for possible use in identification, quality control, and phylogenetic studies of the species.

Methods: $P$. africana leaves, stems, and seeds were fixed, dehydrated in ascending ethanol series (50$100 \%)$, embedded in Technovit resin, and sectioned using a microtome for mounting histological slides for anatomical observation under a microscope and subsequent description.

Results: The anatomical sections of a young stem revealed a cortex consisting of isodiametric parenchyma cells, druse crystals, primary vascular bundles, and pith. The mature stem bark consisted majorly of rhytidome with periderm densely arranged in multiple layers, a cluster of stone cells, and sclerenchyma. The sections of the leaf were hypostomatic with stomata size ranging between 18.90(22.34) $-26.90 \times 15.41-(18.40)-21.22 \mu \mathrm{m}$. The leaf sections showed the presence of characteristic druse crystals, vascular bundles, and mesophyll layers. The pericarp showed the presence of epicarp, mesocarp, and endocarp with a thickness of approximately 350-400, 300-350, and 30-50 $\mu \mathrm{m}$, respectively and a seed testa with a thickness of approximately $50-60 \mu \mathrm{m}$.

Conclusion: The characteristic morphological and anatomical features observed in $P$. africana leaves, stems, and seeds in this study could provide useful data in taxonomical identification of this species.

\section{Introduction}

Plant taxonomy plays a critical role in plant diversity assessment, conservation, phytogeographic deductions, optimum utilization, and inferences (Mukherjee, 2014). As such, the events of plant species misidentification could lead to detrimental results. The genus Prunus (Family Rosaceae) comprises over 400 plant species and displays vast biodiversity globally, although only approximately 98 species of the genus are of great importance, including $P$. domestica (Linn.), P. persica (L.) Batsch, $P$. amygdalus (L.) Batsch, P. cerasoides (D.) Don, P. armeniaca (Linn.), and P. africana (Hook f.) Kalkman (Biswajit et al., 2011). African cherry, also known as Red stinkwood or African almond (P. africana, synonym: Pygeum africanum Hook. F) is an evergreen tree species that occurs within the sub-Saharan countries of Africa including Angola, Burundi, Cameroon, the Democratic Republic of Congo, Equatorial Guinea, Ethiopia, Kenya, Lesotho, Madagascar, Malawi, Mozambique, Nigeria, Rwanda, Sao Tome, South Africa, South Sudan, Swaziland, Tanzania, Uganda, Zambia, and Zimbabwe (Komakech et al., 2019). The genus name Prunus derives from the Latin word that refers to the plum family and the binomial Latin name $P$. africana indicates the African origin of the species (Komakech et al., 2017). P. africana is a highland forest tree, growing in the humid and semi-humid highlands and humid midlands. The wild tree species is found 
mainly in tropical forests at altitudes of approximately $900-3,400 \mathrm{~m}$ above the sea level, with a mean annual rainfall and temperature of $890-2,600 \mathrm{~mm}$ and $18-26^{\circ} \mathrm{C}$, respectively (Komakech et al., 2017). The mature $P$. africana tree is approximately $10-25 \mathrm{~m}$ high with open branches (Fig. 1a). The outer part of the stem bark is corrugated or rough and black to brown in color (Fig. 1b). The leaves are alternate and simple, approximately $8-20 \mathrm{~cm}$ in length, dark green on the top, and pale green at the bottom with mildly serrated margins (Fig. 1C). The flowers are small, white or greenish, hairy, and borne in bunches. The fruits are spherical, purplish-brown, and bilobed, with a thin tough pericarp (Fig. 1d). The seeds are yellowish-brown and oval in shape (Fig. 1e) (Komakech et al., 2017).

\section{-Figure 1-}

Prunus africana has been used in the treatment and management of several diseases including benign prostatic hyperplasia, prostate cancer, gonorrhea, chest pain, fevers, gastrointestinal conditions, urinary disorders, malaria, diabetes, obesity, mental illness, hypertension, infertility, and kidney disease (Steenkamp, 2003; Jimu, 2011; Komakech et al., 2019). Owing to its medicinal importance, a micropropagation protocol for $P$. africana was recently developed to meet the ever increasing demand for it (Komakech et al., 2020). However, as an important medicinal plant, providing features that enhances its accurate taxonomic identification and authentication is pivotal (De Souza et al., 2018). Microscopic observation is one of the important approaches to identify characteristic features that could be used to standardize medicinal plant characterization. Although a study focusing on the anatomy of $P$. africana bark and wood structure has been published (Kotina et al., 2016), there is limited information regarding its leaf, fruit, and seed anatomy. This study thus attempted to provide anatomical characteristics of $P$. africana leaf, seed, fruit, and stem which could be important additional features for its accurate plant identification, quality control, and phylogenetic studies in the future.

\section{Material And Methods}

The Natural Chemotherapeutics Research Institute, Ministry of Health, Uganda provided the $P$. africana sample for the purpose of this study. The voucher specimen number KIOM201901022377 was deposited in the Korean Herbarium of Standard Herbal Resources (Index Herbarium code: KIOM) at the Korea Institute of Oriental Medicine (KIOM), South Korea. The dried leaves and seeds for the anatomy study were stored in water for $24 \mathrm{~h}$, followed by maceration in boiling water for $10 \mathrm{~min}$. An ascending ethanol series (50-100\%) was used to dehydrate the tissues for $1 \mathrm{~h}$ at each concentration. The samples were then embedded using Technovit ${ }^{\circledR} 7100$ (Heraeus-Kulzer, German), based on a previously described protocol (Yeung and Chan, 2015). After complete polymerization, $10 \mu \mathrm{m}$ sections of the resulting resin blocks were prepared using a microtome (SM 2010R; Leica, Wetzlar, Germany) with a tungsten carbide knife. The resin films containing the tissue sections were attached to the glass slides using warm water, followed by staining with Toluidine Blue $O$ before the mounting using Permount $\circledast$ (Fisher Science, Hampton, USA). The slides of the studied material were observed under a microscope (BX53; Olympus,

Tokyo, Japan) and photographed using a digital camera (DP-51; Olympus, Tokyo, Japan). 
For the leaf cuticle morphological observations, living material samples were stored using $70 \%$ ethanol, then cut into small pieces $(1.0 \mathrm{~cm} \times 1.0 \mathrm{~cm})$. For the light microscopic observations, the samples were dipped in $6 \%$ sodium hypochlorite for $8 \mathrm{~h}$. The samples were then thoroughly washed in distilled water. The epidermis of both surfaces of the leaves was peeled off using a single-edge blade (DN-52, Dorco, Seoul, Korea), colored in $1 \%$ safranin-50 \% ethanol for 3 min and mounted in Canada balsam. The mounted slides were examined under a light microscope (Olympus BX-53, Olympus, Tokyo, Japan), and captured using a digital camera (Olympus DP21, Olympus, Tokyo, Japan). The distribution of the epidermal types and stomata density were recorded and compared from the central part of the leaves. The cuticle morphological terminology used to describe the leaves in this study followed previously published indications (Wilkinson, 1979; Evert, 2006).

\section{Results And Discussion}

Leaf morphology plays an integral role in plant taxonomy, identification, and systematics (Viscosi and Cardini, 2011). In this study, the leaves of $P$. africana were observed to exhibit a smooth surface and hypostomatic nature with stomata size ranging 18.90-(22.34) $-26.90 \times 15.41-(18.40)-21.22 \mu \mathrm{m}$ (Table 1). The leaves were also observed to display an isodiametric or irregular cell arrangement (Table 2). Tetracytic and anisocytic stomata complexes and three anticlinal cell wall types (straight, undulated, and straight/curved) were observed on the leaf surfaces (Fig. 2A and B). These stomatal complex types are important factors in accurate plant classification (Abdulrahaman et al., 2009), determination of plant origin, evolution, and phylogenetic relationships (Hong et al., 2018).

Table 1

Overview of representative stomatal characteristics of $P$. africana. HP-hypostomatic; ABabaxial surface; Act-actinocytic; Ani-anisocytic; Ano-anomocytic; Tet-tetracytic.

\begin{tabular}{|llllll|}
\hline Prunus species & \multicolumn{4}{l}{ Stomatal complex } & \multicolumn{2}{l|}{ Size of stomata $(\mu \mathrm{m})$} \\
\cline { 2 - 6 } & Position & Type & Length & Width \\
\hline Prunus africana & HP & AB & Ani, Tet & 18.90-(22.34)-26.90 & $15.41-(18.40)-21.22$ \\
\hline
\end{tabular}

Table 2

Overview of representative leaf epidermal surface characteristics of $P$. africana. AD- Adaxial surface; AB-abaxial surface; Iso-isodiametric, St-straight; cur-curved; und-undulate; ft-flat; DRdruse-shaped crystal; ST-Star-shaped crystal; SS-short simple trichomes; LS-long simple trichomes; GT-glandular trichomes. - absent; +, presence; ++, dominant.

\begin{tabular}{|c|c|c|c|c|c|c|c|c|c|}
\hline \multirow[t]{2}{*}{ Prunus species } & & \multicolumn{3}{|c|}{$\begin{array}{l}\text { Primary } \\
\text { sculpture }\end{array}$} & \multicolumn{2}{|c|}{ Crystals } & \multicolumn{3}{|c|}{ Trichomes } \\
\hline & & Outline & $\begin{array}{l}\text { Anticlinal } \\
\text { wall }\end{array}$ & $\begin{array}{l}\text { Periclinal } \\
\text { wall }\end{array}$ & DR & ST & SS & LS & GT \\
\hline \multirow[t]{2}{*}{ Prunus africana } & $A D$ & iso & und & $\mathrm{ft}$ & - & ++ & - & + & - \\
\hline & $A B$ & iso & cur/st, und & $\mathrm{ft}$ & - & ++ & - & - & - \\
\hline
\end{tabular}


In addition to morphology, leaf anatomy has gained importance as a key tool in plant taxonomy over the years (Araú jo et al., 2010; Kolb et al., 2020). In this study, the transverse-section through the leaf mid-vein and petiole of $P$. africana showed the presence of characteristic druse crystals (Fig. 2C, E, and H), calcium oxalate crystals distributed in all plants and known to protect plants against herbivores (Franceschi and Nakata, 2005). The shape of these crystals is reportedly genetically controlled which explains their consistency in a given plant species (llarslan et al., 2001). The presence of these druse crystals might thus play an important role in plant taxonomy since they occur in various morphological shapes as per given plant species, including druses, prisms, styloids, raphides, and crystal sand that vary from one plant species to another (Konyar, et al., 2014). Previous studies also reported the presence of druse crystals in the leaves of other prunus species including $P$. serotina (Lersten and Horner, 2006) and P. virginiana (Lersten and Horner, 2004).

Our observation showed that the transverse-section of the $P$. africana petiole contained vesicular bundles with prominent xylem vessels arranged in a circular pattern (Fig. 2D and E). The $P$. africana mid-leaf transverse-section revealed the presence of upper and lower epidermal layers with cuticle and a single layer of end-to-end densely packed epidermal cells with large vacuoles (Fig. 2F and G). It is an important structure that protects the plant against moisture loss, microbial, and physical harm (Crang et al., 2018). The palisade layer located on the adaxial side just beneath the upper leaf epidermis was made of closely packed cylindrical cells, and a spongy layer located in the abaxial side of the leaf with loosely arranged irregular shaped cells and wide intercellular space (Fig. $2 \mathrm{G}$ and $\mathrm{H}$ ).

The young stems have green and glabrous surface (Fig. 3A). The anatomical section of the stem showed the presence of a layer of isodiametric cells covered by a smooth cuticle. The cortical parenchyma inner regions contain the intercellular spaces. Sclerenchyma cells were absent. Primary vascular bundles xylem and phloem vessels were arranged in the shape of a ring (Fig. 3B). The pith was centrally located, consisting of spongy parenchyma cells (Fig. 3B-D). The cortex consisted of isodiametric, thin-walled parenchyma cell layers containing druse crystals (Fig. 3D). Druse crystals were observed in the cortex region of the stem. The mature bark is corrugated or rough and black to brown in color. It contains brown dots and/or patches of lenticels and adherent scales (Fig. 3E). The microscopic examination of the stem bark of mature $P$. africana (Fig. 3F) showed mainly the presence of rhytidome-secondary phloem and the oldest periderm densely arranged in multiple layers (Fig. 3G). Furthermore, a cluster of stone cells was observed scattered among the rhytidomes. Sclerenchyma was observed within the phelloderm of mature stems (Fig. 3H).

The structures observed in $P$. africana stem bark including the periderm in multiple layers, intercellular spaces, secondary phloem, the sclerenchyma tissues, occurrence of druse crystals, almost exclusively simple perforation plates, and stone cells are shared by other prunus species that were previously studied including P. serotina, P. Avium, P. Pennsy/vanica, and P. Pennsy/vanica (Bastin, 1895); indicated that they all belong to the genus Prunus. 
The anatomy of the $P$. africana pericarp showed the presence of epicarp, mesocarp, and endocarp with a thickness of approximately 350-400, 300-350, and 30-50 $\mu \mathrm{m}$, respectively, and vascular bundles (Fig. 4A, B, C).

Seed anatomy plays a vital role in the taxonomy of plants (Vaughan, 2009). In this study, the transverse section through the seed of $P$. africana showed the presence of testa with a thickness of approximately 50-60 $\mu \mathrm{m}$, plumule, and sclenchyma tissue.

\section{4.conclusions}

The internal structures of the plants play critical roles in the understanding of the relationships between the taxa. Consequently, the results obtained in this study will play a crucial role in the taxonomy of $P$. africana.

\section{Declarations}

\section{Authors contribution}

RK conceived the original research plans, collected experimental materials, conducted the experiments, and wrote this manuscript. SY, JHS, and GC carried out anatomical study and authentication of the $P$. africana used in this study. YGK wrote the manuscript. FO and GNK collected the sample, wrote, and revised the manuscript. MGM technically revised the manuscript. YK supervised all the experiments and is the corresponding author.

\section{Ethics approval and consent to participate}

Not applicable

\section{Data availability}

The raw data supporting the results of this article will be made available through the corresponding author upon reasonable request.

\section{Competing Interest}

The authors declare no conflict of interest.

\section{Funding}

This research was funded by the framework of International Cooperation Program (Korea-South Africa Cooperative Research Project for Excavation of Candidate Resources of Complementary and Alternative Medicine) managed by National Research Foundation of Korea (grant no. 2017093655 and KIOM: D17470). Additionally, this work was also supported by Development of Foundational Techniques for the Domestic Production of Herbal Medicines (K18405), Development of Sustainable Application for 
Standard Herbal Resources (KSN2013320), Korea Institute of Oriental Medicine through the Ministry of Science and ICT, Republic of Korea.

\section{References}

1. Abdulrahaman A, Egbedo FO, Oladele F (2009) Stomatal complex types, stomatal density, and the stomatal index in some species of Dioscorea. Archives of Biological Sciences. 61. 10.2298/ABS0904847A

2. Araú jo SJ, Azevedo AA, Silva CL, Meira AS (2010) Leaf anatomy as an additional taxonomy tool for 16 species of Malpighiaceae found in the Cerrado area (Brazil). Plant Syst Evol 286:117-131

3. Bastin ES (1895) Structure of our cherry barks. The American Journal of Pharmacy 67:435-453

4. Biswajit D, Ahmed N, Pushkar S (2011) Prunus diversity-early and present development: A review. International Journal of Biodiversity Conservation 3:721-734

5. Crang R, Lyons-Sobaski S, Wise R (2018) Epidermis. In: Plant Anatomy. 279-318. https://doi.org/10.1007/978-3-319-77315-5_9

6. De Souza FMD, Sá DR, Araújo E, Randau PK (2018) Anatomical, phytochemical and histochemical study of Solidago chilensis Meyen. Anais da Academia Brasileira de Ciências 90:2107-2120

7. Evert RF (2006) Esau's Plant Anatomy. Wiley-Interscience, New Jersey. 2006; 601p

8. Franceschi RV, Nakata AP (2005) Calcium oxalate in plants: Formation and function. Annual Review of Plant Biology 56:41-71

9. Hong T, Lin H, He D (2018) Characteristics and correlations of leaf stomata in different Aleurites montana provenances. PLOS ONE. https://doi.org/10.1371/journal.pone.0208899

10. Ilarslan H, Palmer RG, Horner HT (2001) Calcium oxalate crystals in developing seeds of soybean. Ann Bot 88:243-257

11. Jimu $L$ (2011) Threats and conservation strategies for the African Cherry (Prunus africana) in its natural range-A review. Journal of Ecology Natural Environment 3:118-130

12. Kolb LK, Gomes AMS, Lombardi AJ (2020) Leaf anatomy as a taxonomy tool for the identification of Brazilian native species of Chionanthus (Oleaceae). Flora. 266: 151-590

13. Komakech R, Kang Y (2019) Ethnopharmacological Potential of African Cherry [Prunus africana]. J Herb Med. https://doi.org/10.1016/j.hermed.2019.100283

14. Komakech R, Kim YG, Kim JW, Omujal F, Yang S, Moon CB, Okello D, Rahmat R, Kyeyune NG, Matsabisa GM, Youngmin Kang Y (2020) A Micropropagation Protocol for the Endangered Medicinal Tree Prunus africana (Hook f.) Kalkman: Genetic Fidelity and Physiological Parameter Assessment. Front Plant Sci. https://doi.org/10.3389/fpls.2020.548003

15. Komakech R. Kang Y, Lee JH, Omujal F (2017) A Review of the Potential of Phytochemicals from Prunus africana (Hook f.) Kalkman Stem Bark for Chemoprevention and Chemotherapy of Prostate Cancer. eCAM. https://doi.org/10.1155/2017/3014019 
16. Konyar TS, Öztürk N, Dane F (2014) Occurrence, types and distribution of calcium oxalate crystals in leaves and stems of some species of poisonous plants. Botanical Studies 55. https://doi.org/10.1186/1999-3110-55-32

17. Kotina EL, Oskolski AA, Tilney PM, Van Wyk BE (2016) Bark and wood structure of Prunus africana (Rosaceae), an important African medicinal plant. South African Journal of Botany 106:89-95

18. Lersten RN, Horner TH (2004) Calcium oxalate crystal macropattern development during Prunus virginiana (Rosaceae) leaf growth. Canadian Journal of Botany 82, https://doi.org/10.1139/b04-145

19. Lersten RN, Horner TH (2006) Crystal macropattern development in Prunus serotina (Rosaceae, Prunoideae) Leaves. Ann Bot 97:723-729. doi:10.1093/aob/mcl036

20. Mukherjee A (2014) Botanical identification of medicinal plants: A biosystematics contemplation. Indian J.Sci.Res. 9, 076-083, 2014. DOI: 10.5958/2250-0138.2014.00013.3

21. Steenkamp V (2003) Phytomedicines for prostate. Fitoterapia 74:545-552

22. Vaughan JG (1968) Seed anatomy and taxonomy. Proceedings Linnean Society London, 179, $251-$ 255

23. Vincenzo V, Cardini A (2011) Leaf Morphology, Taxonomy and Geometric Morphometrics: A Simplified Protocol for Beginners. 6, e25630. https://doi.org/10.1371/journal.pone.0025630

24. Wilkinson HP (1979) The plant surface (mainly leaf). In: Metcalfe CR, Chalk L, editors. Anatomy of the cotyledons, 2nd ed. Oxford, UK: Clarendon Press. 1, 97-165

25. Yeung EC, Chan CKW (2015) Glycol methacrylate: the art of embedding and serial sectioning. Botany 93:1-8

\section{Figures}




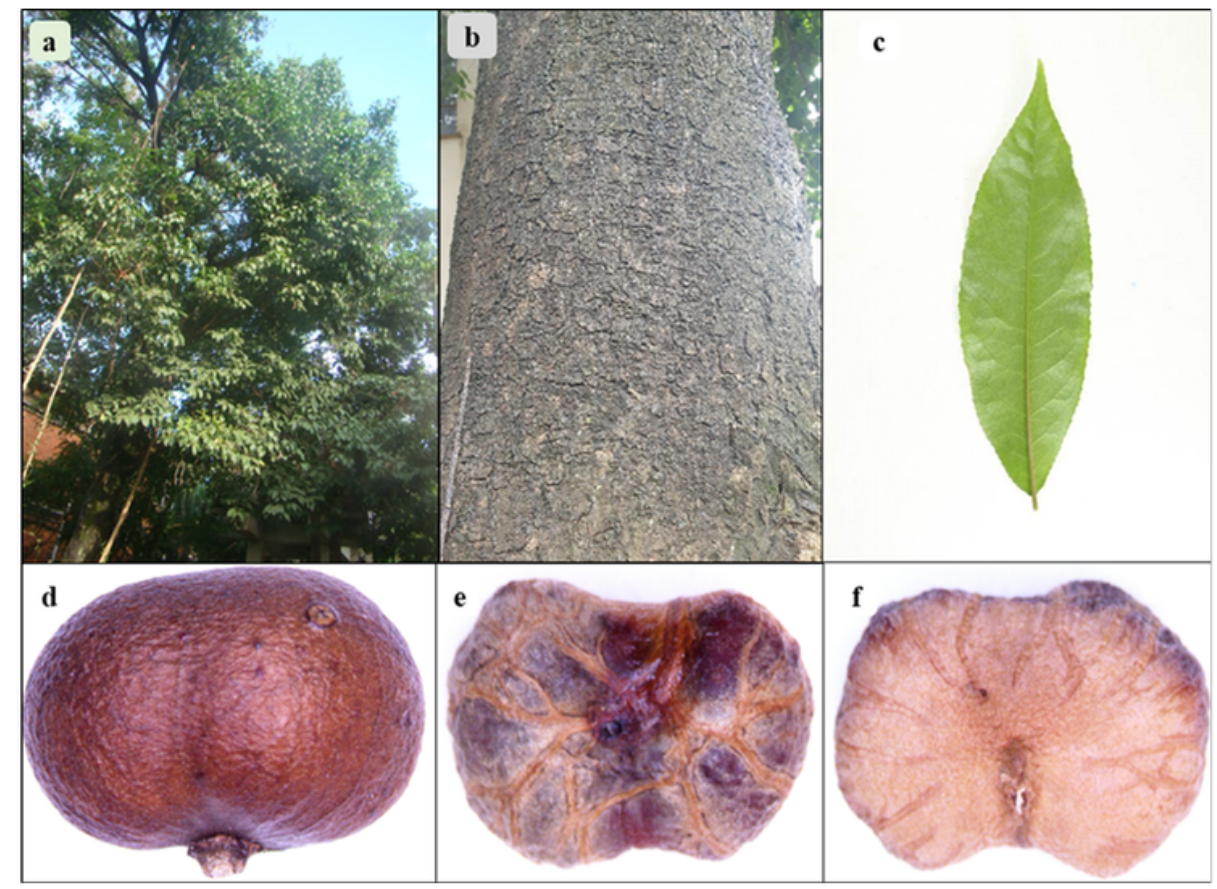

Figure 1

\section{Figure 1}

Botany of Prunus africana. a. P. africana tree. b. Stem of P. africana with part of its bark harvested for medicine purpose. c. Leaf of P. africana. d. Fruit of P. africana. e-f. Seeds of P. Africana

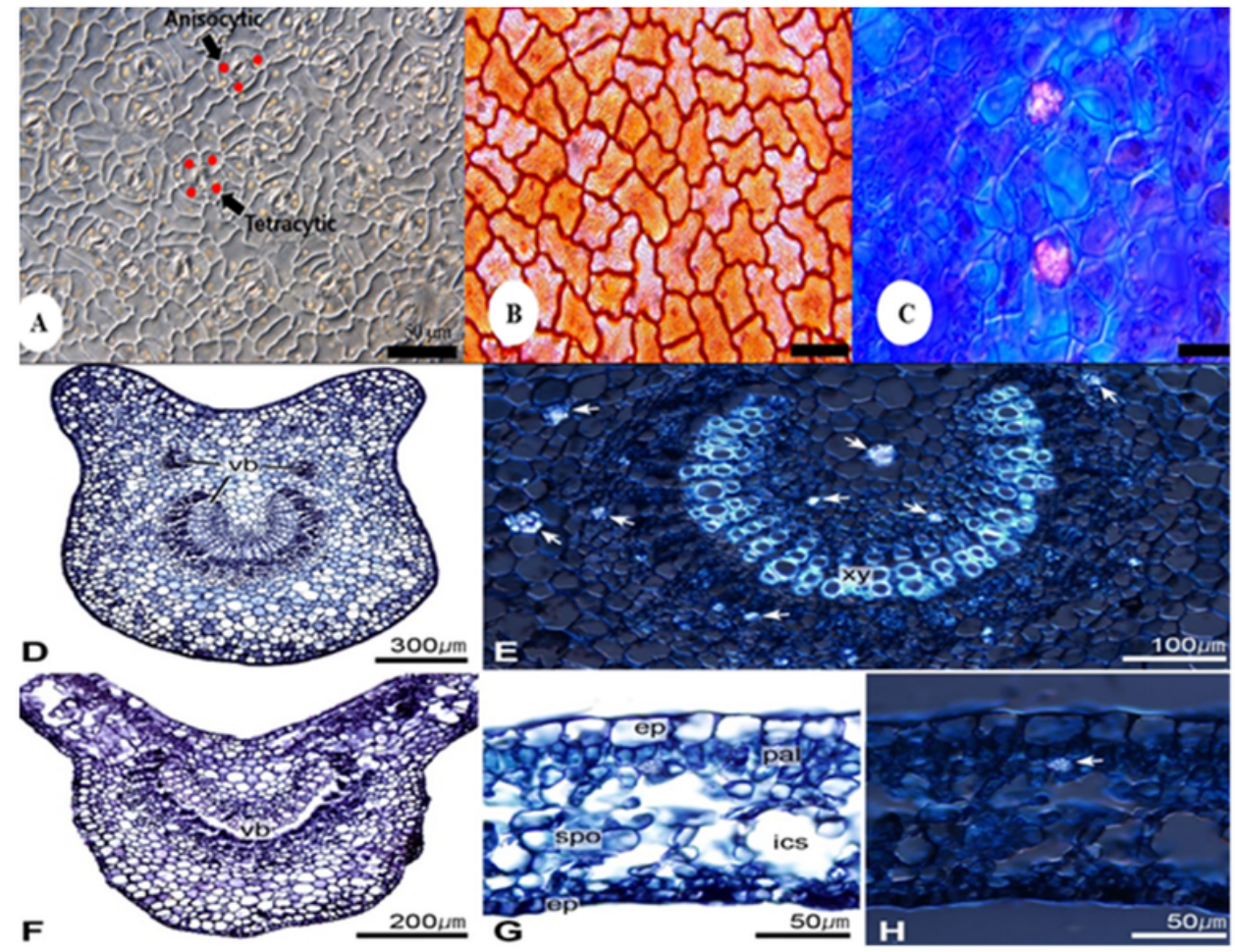

Figure 2 


\section{Figure 2}

Light microscope micrographs of leaf characteristics of P. africana. A. Leaf adaxial surface. B. Leaf abaxial surface. C. Druse-shaped crystals. D, E: transverse sections of leaf petiole, F-H: transverse sections of leaf blade. C, E, H: Observation was made on DIC mode of light-microscope. ep: epidermis, ics: intercellular space, pa: palisade parenchyma, spo: spongy parenchyma, vb: vascular bundle, $x y$ : xylem, arrows: druse crystal. Scale bars for A-B: $50 \mu \mathrm{m}$; C: $20 \mu \mathrm{m}$.

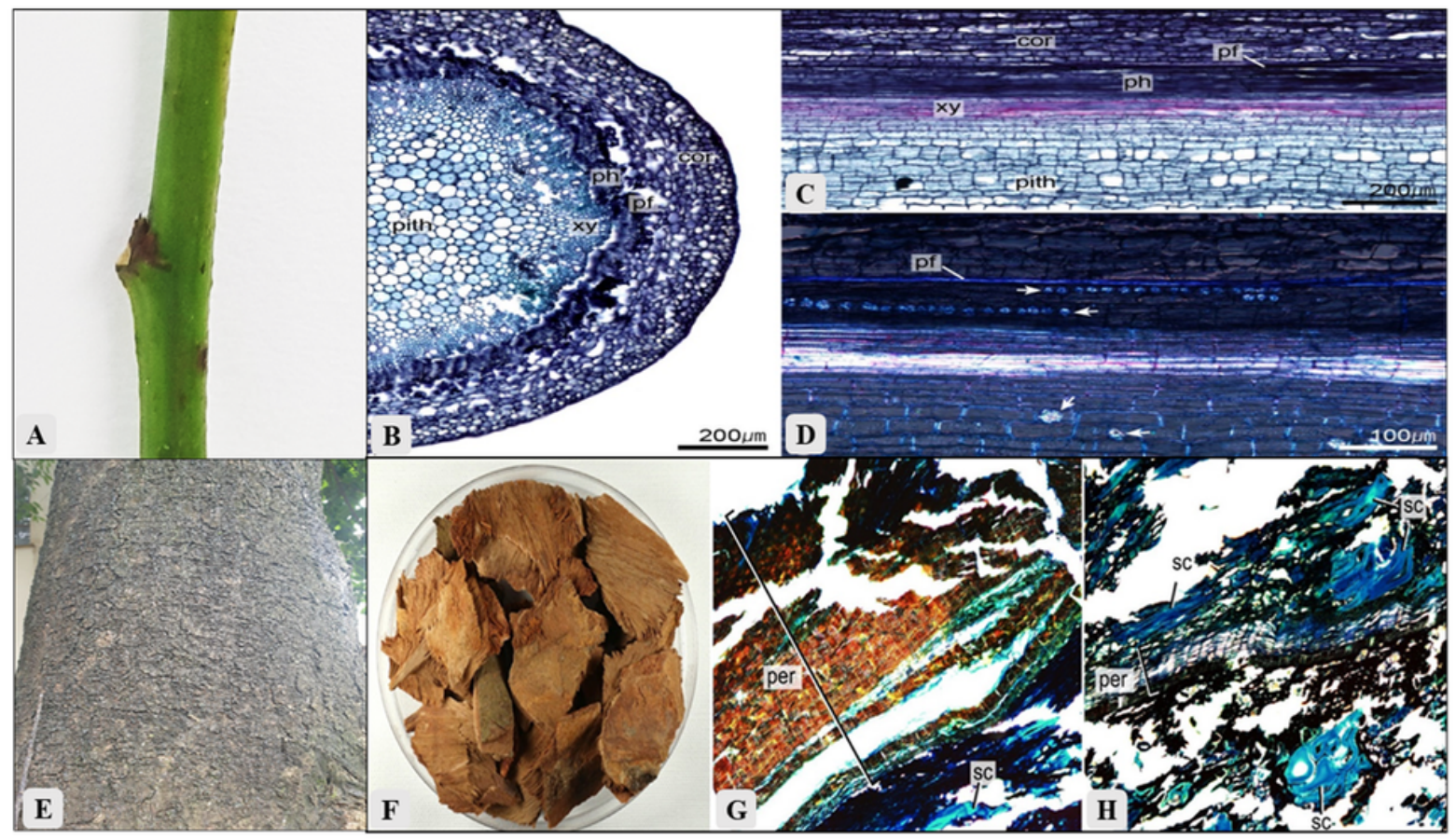

Figure 3

\section{Figure 3}

The stem morphology and anatomy of Prunus africana. A. Young stem morphology. B: Transverse section of a young stem. C-D: Longitudinal sections of a young stem. E. Mature stem bark morphology. F. Dried stem bark. G-H. Rhytidome. Observation on DIC mode of light-microscope. cor: Cortex. ep: Epidermis, pf: Phloem fiber, ph: Phloem, xy: Xylem. Arrows: Druse crystal. per: Periderm, sc: Sclerenchyma. $\mathrm{G}$ and $\mathrm{H}$ scale of $200 \mu \mathrm{m}$. 


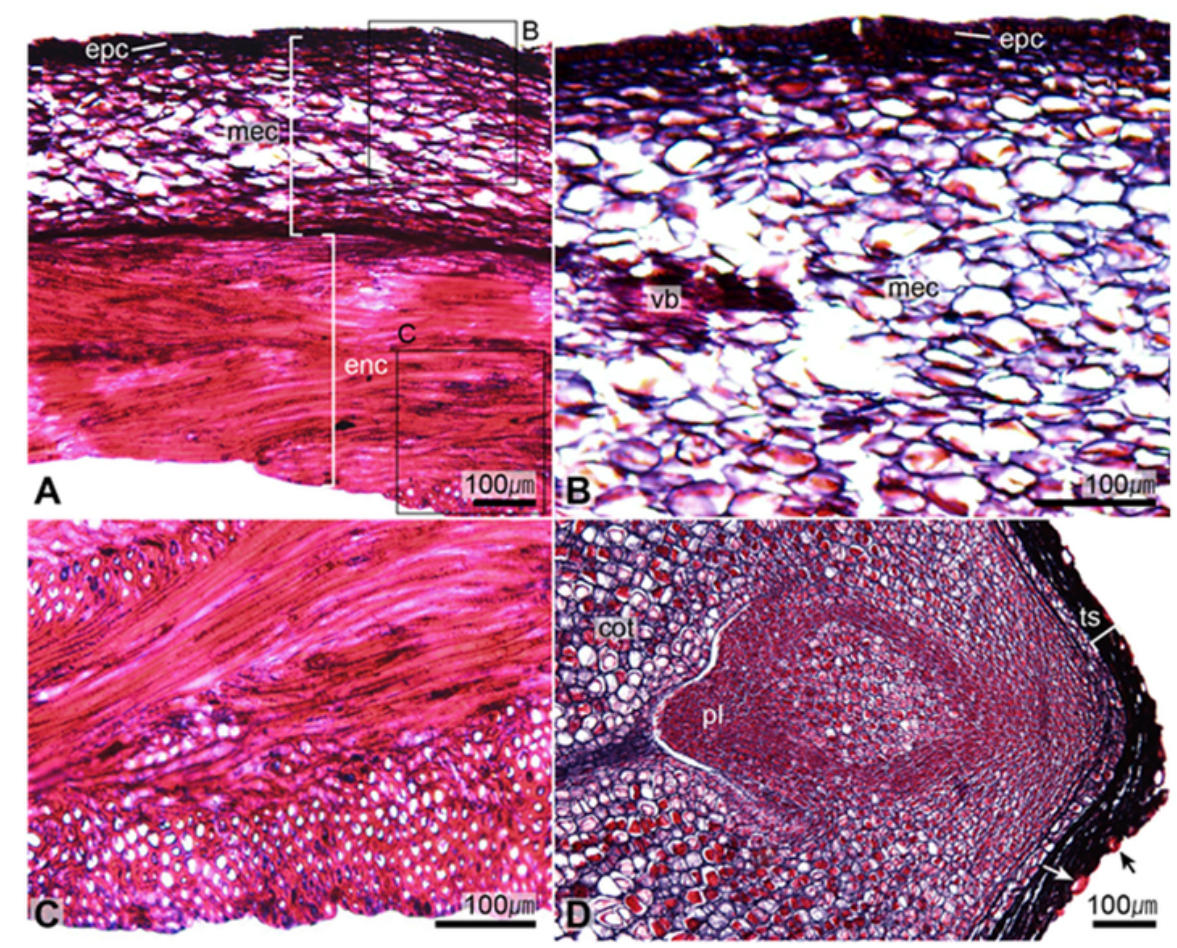

Figure 4

\section{Figure 4}

Fruit and seed anatomy of Prunus africana. A, B, C: transvers section of pericarp. D: Transvers section of seed. epc: Epicarp, mec: Mesocarp, end: Endocarp, vb: Vascular bundle. cot: cotyledon, pl: Plumule, ts: Testa. Arrows: Sclenchyma. 